Pedro L. C. Cavalcante' ${ }^{1}$, Gabriela S. Lotta ${ }^{2}$ e Erika M. K. Yamada ${ }^{3}$

\title{
Exploring mid-level bureaucracy: a tentative typology
}

Explorando a burocracia de médio escalão: uma tentativa de tipologia

\section{Introduction}

The paper's main goal is to present an original typology of bureaucrats, situated in the intermediate layer of the civil service structure. This specific set of players, the mid-level bureaucrat (MLB), is seen as a strategic group, primarily, because of its connection role and position between the top officials and the policy executors. A deeper understanding about this group is central in order to contribute both for the incipient literature on the subject as for the empirical knowledge of the Brazilian public administration.

The literature has already pointed out the importance of MLB in policymaking, as they play an important role in establishing and operating different kinds of relationships, in regulating communication and information and also in connecting the formulation and implementation processes (Pires, 2015; Huising and Silbey, 2011; Keiser, 2010; Mintzberg, 1973; Cavalcante e Lotta, 2015). At the same time, the literature also shows that they are composed by heterogeneous groups. MLBs are also different in a variety of forms - profile, experience, way of working, among others, which

\footnotetext{
Public policy manager - Institute of Applied Economic Research (Ipea) - Brasília, DF, Brazil. 
are normally influenced by a comprehensive range of factors. As Cavalcante and Lotta (2015, p 302) point out: “(..) the complexity, characteristics and natures of the policies and organizations generate different forms of actions and performances of the MLBs and in order to understand this particular player it is also essential to analyze the institutional environment they operate in."

Bureaucrats heterogeneity is one of the most recurring subjects in the literature, specially, because it helps to comprehend who they are and how they perform, including internal or external interaction, degree of discretion, scope and technical nature of their decisions, isolation or exposure to political issues, etc. The differences between the MLBs regarding the roles and functions they play in policymaking are also highlighted. For instance, Mintzberg (1973) argues that, due to the managers' performance diversity, they could be framed in three general categories of functions: interpersonal, informational and decisory. Besides, these bureaucrats perform, at the same time, technical and managerial activities combined with political activities, i.e., translating strategic decisions in policies (Pires, 2011). It is precisely this capacity of merging technical and political skills and the position in the organizational structure that are the key factors that make mid-level bureaucrats influential during the processes of policy decision-making (Currie and Procter, 2005; Kelly and Gennard, 2007).

As we will discuss further, despite their relevance and well-known heterogeneity, few studies have explored this diversity and the effects in the policymaking. Nevertheless, some of these researches combine theoretical and empirical efforts in order to investigate civil servants heterogeneity. First, scholars have been primarily concerned with hierarchy, focusing analysis on specific groups of bureaucrats, such as the street level (Lipsky, 1980) or the top rank officials (De Bonis, 2008; Dror, 1996; Longo, 2007). Second, analyses of their motivations and behaviors have also been used to compare bureaucrats (Downs, 1967; Schneider, 1994). In the same sense, important inquiries have investigated comparatively the bureaucrats' effects on economic development and on policymaking. For 
instance, Evans and Rauch (2014) research of the Weberian states and researches that use merit and capacity indexes to create typologies of Latin American public servants (IADB, 2006).

None of them, however, specifically applies to MLBs, which converges with Lotta, Pires and Oliveira (2015) that, based on extensive research of international literature, outline a great number of gaps that still need to be overcome by empirical studies.

In this context, this research addresses the following questions. Are the mid-level bureaucrats heterogeneous? If so, how? Is it possible to map different subgroups among MLBs? Which dimensions differ the most among them? In order to answer these questions and help fulfilling this knowledge gap, this paper proposes a typology that includes crucial dimensions, such as profile, background and performance.

Therefore, survey data collected in 2014 from federal mid-level bureaucrats with commissioned positions was employed, known as DAS, 1-5. It is worth explaining that in the structure of commissioned positions in the Brazilian federal government, there are six positions denominated DAS (Management Positions or Higher Advisory), ranging from 1 (lowest) to 6 (highest) and $N E$ (Special Nature Positions) superior to DAS 6. Considering this structure, the positions can be defined as: servers without DAS: low-level; DAS 1 to 5: mid-level (subject of this research); and 6 and NE: high-level. The sample, over seven thousands respondents, was quite significant, about $30 \%$ of the population, and also representative of different segments (ENAP, 2014).

In addition to the simple variables, it was also formulated synthetic indicators to measure the bureaucrats' degree of relationship and activities (Index of MLB Relationships - IBR and Index of MLB Activities - IBA). Then, a cluster analysis was employed to identify similar groups and build an exploratory MLB typology. Therefore, the complete-linkage clustering (farthest neighbor) was employed, which focuses at grouping together successive sets of variables or individuals until the similarity measure between them starts to decrease (Johnson and Wichern, 2007). 
The empirical results were quite interesting. The cluster analysis provided five distinguished types that were used to classify and discuss the MLB groups with an illustrative reference to the hierarchical structure of the social classes in the European Feudalism period. The typology demonstrated the existence of an elite of mid-level bureaucrats, such as nobles, vassals and knights. However, even inside this prominent segment there is hierarchy. Considering the performance dimensions (influence, relationship and activities), nobles are at the top, followed by vassals and knights, in this particular order. The pyramid basis, composed by two types - merchants and farmers - is very far from the elite, mainly because they have, overall, less qualification and resources.

Following this introduction, the second section discusses the existing bureaucrats' typologies. Next, the methods and variables of the empirical analysis are presented. Then, the mid-level bureaucrats' types and characteristics are discussed. Finally, some conclusions are debated.

\section{Bureaucrats' Typologies}

In recent years, there has been an increase of studies towards the comprehension of the civil servant, both in terms of its role and profile. Although the literature has achieved important findings understanding how bureaucrats work, there is still a gap regarding the types of existing and active bureaucrats in different governments. At the same time, although the literature already demonstrates that bureaucrats are heterogeneous and take part on diverse groups and even propose some kinds of typologies, there is barely any progress in understanding specific groups of bureaucrats in a more comprehensively way, specially the MLBs.

It can be argued here that the typologies available in the literature only consider few aspects, such as structure or sectors, but still lacks the different aspects about profile, hierarchy and performance. The idea of a tentative typology of mid-level civil servants addresses this gap and aggregate dimensions that highlight their characteristics in 
order to corroborate the discussions about the implications of these differences for the policymaking.

Therefore, the analytical foundations must consider the existing diversity not just in terms of profile, but, above all, regarding their hierarchical position, performance, responsibilities and relationships during the policymaking process.

In this section, the typologies available in the bureaucracy's literature is discussed in order to demonstrate the relevance of this investigation strategy in the field of study.

A first taxonomy focuses on the hierarchical position. The difference between high-level, mid-level and more operational level bureaucracies is present in the literature since its beginnings, associating hierarchy and functional structure elements with degree of responsibility and politicization. In this typology, bureaucrats are sorted accordingly to their functions in the policymaking process, i.e., formulation and implementation stages.

Top officials, also called the high level bureaucracy, in general, work directly associated with the formulation phase and the political sphere, thus their performance tends to be more political (Loureiro et al., 2010). Part of the literature also associates this layer of the bureaucracy to the idea of public officials, as they assume managerial positions that lead or manage the decisions of other strata of bureaucracy (De Bonis, 2008; Dror, 1996; Longo, 2007). With regards to high-level, scholars have investigated how the appointment process (recruitment and selection) operates, especially considering systems in which the occupation of senior roles is restricted to commissioned positions, highly influenced by political aspects. For instance, the research of Lopez et al. (2014) deepen the understanding of the bureaucrat's appointment processes in the Brazilian federal government, covering their political and partisan ties, tenure and turnover, technical knowledge or political connection.

The mid-level bureaucracy consists of a large set of heterogeneous individuals occupying intermediate positions in the administration. Establishing a relationship between the top (high-level) 
and operational base of organizations, MLBs have their overall performance linked to the idea of translation between political and technical dimensions. Besides, scholars have sought to understand aspects related to the organizational locus and values, types of activity, leadership, relationships, etc (Lotta, Pires, Oliveira, 2014). This literature has two recurrent themes. The first concerns the relationships established by them - a vertical (relations with bosses and subordinates) and horizontal logic (interaction with intra and inter peers) (Pires, 2015). The second issue relates to understanding how, from their relational activities, these players regulate the interaction between different areas of the organization and between different organizations (Huising and Silvey, 2011).

The operational bureaucracy, usually linked to the policy implementation phase, also involves a more structured set of studies aimed to understand the actions of those who directly perform services to citizens, the so-called street-level bureaucrats. However, the literature has devoted little attention to the bureaucrats in the "backstage", in other words, the low-level bureaucracy without commissioned positions and no direct contact with citizens (Hoyler and Campos, 2016). On the contrary, the bulk of the studies has emphasized how street-level bureaucracy makes its decisions, interacts with citizens, how their values interfere on their discretion, managerial and organizational factors that affect their operations, networks and relationships (Hupe at al., 2015; Maynard and Musheno, 2003; Lotta, 2015; Spinelli, 2016; Pires, 2009). More recent inquiries have focused on understanding factors such as the accountability of these bureaucrats, a direct reference to the idea of the legitimacy in decision-making process (Hupe, 2007) and inclusive or exclusive dimension of their work (Dubois, 1999; Maynard and Musheno, 2003).

Therefore, this classical typology seeks to understand the bureaucracy from different hierarchical layers and has brought important insights to the literature, but still lacks researches on the internal heterogeneity and how the differences across different bureaucrats 
levels are determined by relevant dimensions such as policy sector, politicization, behavior or organizational values.

Other taxonomy involves the chain of command, that is, who decides and who performs. Some scholars analyze the bureaucracy role, grounded in the logic of the principal-agent model, considering agents as those obeying the commands determined by the principals. In other words, it is not an established typology, nevertheless, it allows us to understand the existing informational gaps in the operative chain. In this model, the agent generally has a level of information about policy issues higher than the principal, especially because the latter is not directly involved in the details of policymaking. The principal, in turn, knows the agents' utility curve and can provide incentives for them to perform better. Consequently, this informational asymmetry is as interesting reference to differentiate the performance among bureaucratic agents and principals (Waterman and Wood, 1993).

Other set of typologies in the field of study investigates the difference of the bureaucrats focusing on their preferences, motivations and interests in the public sector.

One of them is the Anthony Downs (1967) research that differentiates bureaucrats by their behaviors. Grounded on Public Choice theory, the author assumes that bureaucracy pursues rationally their goals and its utility maximizers. These agents, at the same time, have multiple objectives, such as power, income, security, prestige, excellence at work and pride for serving the public, among others. These individual motivations are also constrained by contextual elements, which stimulate certain behaviors and can generate access to certain information differently among agents. Based on this diversity of interests and motivation, Downs (1967) establishes a typology of five bureaucratic groups.

The first one, so-called climbers, are purely self-interested agents that also value power, income and prestige. They seek promotion to higher hierarchical positions or jobs in other organizations linked to income and prestige. The second group, conservers, seeks to maximize security and convenience, clinging to all that they 
have earned as income and power. They avoid change and, hence, become attached to rules and procedures. The advocates are loyal to the organization functions or the organization as a whole and seek power to influence policies and actions (Oliveira, 2007). Their goal is to increase the support and resources in order to strengthen their policies. The fourth group, the zealots, has political loyalty or narrow and specific concepts and look for power in order to satisfy their beliefs, to which they concentrate energy and resources (Oliveira, 2007). They try to overcome the obstacles and attack the status quo, pursuing changes to policies. Lastly, the statesmen are committed to the society as a whole and believes in the pursuit of the "public interest". Therefore, they perform trying to influence policy at the national level. These bureaucrats defend the expansion of non-partisan political way and try to isolate the administrative activities (Oliveira, 2007).

Downs (1967) points out that, although the typology shows different motivations and interests, it is not inert. Bureaucrats can change their behavior over time, from one type to another, or by changes in their motivations, either by changes of context.

Ben Schneider (1994) formulated another important study concerning public servants' motivations and behaviors. By analyzing different cases of industrial policies in Brazil, the author discusses the preferences of bureaucrats and their relationship with others interests in politics. As results, bureaucrats map, along their career, different goals - some more personal, others directed to policies. Thus, Schneider (1994) reaches four types of careers in the case analyzed: military, political, technical and technic-political. As they cannot achieve all the objectives at the same time, the bureaucrats make strategic choices, which are the careers calculations (Oliveira, 2007) and understanding these different career paths helps to know the bureaucracy's preferences.

Although these behavioral approaches enriches the analysis of the bureaucracy, they still lack a more interdependent understanding regarding the type and nature of policymaking involved and the responsibilities assumed by the bureaucrats in their daily work. 
In this regard, another set of interesting typologies focus on differentiating the bureaucrats from the organizational locus or nature of the policies in which they operate. In studies of management and especially in organizational studies, for example, it is common to find a distinction between the bureaucrats of the middle areas or executive areas - considering that the former are more concerned with administrative activities, with little interaction with final users or external public; while the latter focuses at carrying out the policies and interacting more directly with the external public. Another typology relates to the sectors where these bureaucrats act: social , economic, infrastructure, government sector, etc. Recent studies show that there are important disparities in the bureaucrats' profile and performance considering the sectoral differences (Cavalcante at al., 2015). The same logic applies to the bureaucracy types based on the nature of the policies in which they work (regulatory, distributive and redistributive). Although this field of study is barely explored, there are demonstrations that different policy natures are associated with different types of bureaucracies, especially with regard to their duties and responsibilities (Brehm and Gates, 1997).

Also with respect to political and bureaucratic dimensions, an important study of Evans and Rauch (2014) helps to understand the relation between bureaucracy's types and economic development. Focused on different characteristics of the state economic institutions in emerging countries between 1970-1990, the authors apply the so-called "Weberian Scale" in order to evaluate the degree of implementation of "Weberian" actions in these countries and to which extent they contribute to the economic growth measured by GDP per capita and human capital.

Starting from the thesis that the degree of bureaucratization, in the Weberian sense of the term, is a dimension of the countries' growth, the authors analyze "the degree to which the central state agencies are characterized by meritocratic recruitment and offer structured career progression and bonus performance" (Evans and Rauch, 2014, p. 411). From the empirical analysis and comparing the Weberian scale in several countries, the authors demonstrate 
that the relationship between the scale and economic growth is strong and significant, so that the scale has a powerful impact on economic growth.

This evidence, as the authors argue, "reinforces the proposition that state bureaucracies characterized by meritocratic recruitment and predictable and rewarding careers are associated with higher growth rates" (p. 429). Thus, the analysis of the Weberian State variables helps to characterize the different states and the role of the bureaucracy and can, therefore, be an analytical tool to the composition of a bureaucrat's typology.

A similar analytical approach was adopted by the Inter-American Development Bank's publication The Politics of Policy (IADB, 2006). Assuming that bureaucracy is one of the institutional foundations for effective functioning in the democratic system, the report analyzes different indicators of strength and institutionalization bureaucracy in governments. The central idea is that the weakness or strength of the bureaucracy strongly contributes to the policy results in Latin American nations. Bureaucratic weakness is one of the causes for the historically ineffective development of these countries.

Bureaucracy is responsible for different roles in decision-making and the more neutral and professional their operations, the greater the guarantee of stability, adaptability and public interest goal in policies. Based on these assumptions, the report proposes a set of qualitative and quantitative tools to examine "the extent to which bureaucracies are endowed with the institutional attributes required to perform the regulatory roles assigned to them in a representative democracy" (IADB, 2006, p. 65).

The study has been developed by comparing 18 countries in the region. One of the measures adopted was the degree of autonomy of the bureaucracy, which evaluates the degree to which effective guarantees of professionalism in the civil service are in place and the degree to which civil servants are effectively protected from arbitrariness, politicization, and rent-seeking (IADB, 2006). 
The analysis shows that there are three groups of countries, separated according to their performance on the indicator. The first one (of which Brazil is a part) shows a widespread acceptance of the principles of merit in decisions regarding the hiring, promotion, and dismissal of public officials". The second group has "practices based on merit coexist with traditions of political patronage. The third group reflects strong politicization of decisions on hiring, promotion, and dismissal (IADB, 2006).

The second indicator, the functional capacity index, covers the ability of bureaucracies to formulate and implement public policies, considering their technical capabilities and appropriate incentives for effective performance. Therefore, the indicator measures characteristics such as salary compensation system and evaluation system of the servant's performance.

From the intersection between the two indicators, the report groups the countries of Latin America in three different degrees of bureaucratic development.

The first group has bureaucracies with minimum development, in which the civil service system cannot guarantee the attraction and retention of competent personnel, and lacks the managerial mechanisms necessary to promote efficient performance on the part of civil servants. The second group shows the countries where public service systems are fairly well structured but that have not been consolidated in terms of merit guarantees and management tools that would allow for an effective utilization of its capabilities (IADB, 2006). The third and final group, in which Brazil is located, is composed of countries with a high degree of institutionalization - comparatively - despite having systems with different characteristics.

Finally, the quality indicator of the bureaucracy is constructed from a combination of metric indices and functional capacity with an efficiency indicator that measures the percentage of the total employed population in the public service. The result of this combination is a typology of bureaucratic types to formulate, organized into four different types: 
1) Administrative bureaucracy: It is characterized by a low capacity and high relative degree of autonomy. For the authors, it is usually related to a partial or failed attempt to develop a traditional Weberian bureaucracy. Civil servants are hired based more on political than meritocratic criteria, but they have some job security. The degree of their technical competence and orientation toward good performance is low (IADB, 2006). This bureaucracy has, therefore, limited abilities to act in a more active and influential way in the decision making process of public policies, whose decisions are generally associated with the ministers. It is the bureaucracy with a more focused role in the implementation of policies, although with a tendency to formalism and control procedures and not the effectiveness of policies.

2) Clientelistic Bureaucracy: This group is characterized by low autonomy and low capacity. It is based on a high turnover of positions associated strongly to political loyalty or party affiliation. This rotation, in turn, affects the stock of human resources of the State. The role of these bureaucracies to formulate is related to their nature primarily as a political resource of the governing party to exchange jobs for votes or political support. This type of bureaucracy is an extension of the political party. There are potential conflicts with other professional and meritocratic segments of bureaucracies to formulate, competing for their ideas and roles in the design of policies.

3) Parallel bureaucracy ("technical teams" or "project teams"): typology based on the low autonomy and high capacity. Bureaucracies are formed in a job system logic, based on hiring committed managers by flexible contracts. Therefore, those contracted are not part of the permanent structure and can be renewed constantly. The central feature is not party affiliation but specific knowledge and recognized in certain policy areas (logic of "technopolitical"). They find relative 
degrees of resistance from other bureaucratic actors and their success varies from case to case.

4) Meritocratic bureaucracy. Type formed by a high degree of autonomy and high capacity with different combinations. Bureaucracies are composed of stable civil servants recruited based on merit and incorporated into the state careers. May have incentive systems based on its own merits and capabilities.

The authors argue that the countries in Latin America are very heterogeneous and composed of different organizations marked by distinctive characteristics, namely the heterogeneity, also reflected internally in states. This differentiation and typology, however, helps to advance the understanding of development levels and capacity of the bureaucracies.

\section{Mid-level bureaucrats: a tentative typology}

\section{Variables and Methods}

One important assumption in the literature is that mid-level bureaucrats are heterogeneous, considering a vast range of dimensions, such as profile, professional background and performance, among others. Based on that, the survey data collected in 2014 from Brazilian federal mid-level bureaucrats with commissioned positions was explored, known as DAS 1-5, to create a typology. As mentioned before, the sample covers over seven thousands respondents, approximately $30 \%$ of the MLBs' population, and it's also highly representative in different perspectives (ENAP, 2014).

In order to achieve the paper's purpose, a set of variables was selected, including simple and synthetic or composite ones, all provided by the survey above-mentioned. Then, the data was divided in four dimensions: profile, job attachment, professional background and performance. The choice for the first dimension stems from the relative consensus in organizational field of study that age and educational level may differentiate employees' motivation and capability. The options for job attachment and professional 
background are justified in the bureaucrats' literature concerning Weberian aspects of autonomy and meritocracy (Evans and Rauch, 2014; Cavalcante and Lotta, 2015; Lopez, 2015). Lastly, the performance dimension is depicted by three variables: relationship, influence and activities.

As the literature argues, the relational dimension of MLBs is important to explain their performance, position and interactions. At the same time, this dimension is the one that differentiates the MLBs from the other levels of civil servants in the policymaking process, as they take responsibility and locus for establishing relationships between different kinds of actors (Kuratko et al, 2005; Keiser, 2010). This literature also demonstrates that MLBs perform operating two different axis of relationships: the horizontal one (with peers) and the vertical one (with superiors and subordinates) (Pires, 2015) and, therefore, they become gatekeepers of information, communication and relationships. This is the idea that MLB act on regulatingrelationships and also managing the gaps between rules and practices (Huising and Silbey, 2011; Keiser, 2010). Besides, MLBs have, or develop, an ability to influence decisions. This capacity, however depends on the combination of technical and specialization and management skills (Kelly and Gennard, 2007); hierarchical position; level of conflict with different professionals (Currie and Procter, 2005); and sensitivity to understand the strategic context of the organization (Kuratko et al., 2005). As pointed out before, by analyzing the different kinds of MLB performance, Mintzberg (1973) points out that there can be categorized 3 different functions performed by them: interpersonal, informational and decisional.

Regarding the profile, civil servants age and educational level, ranging from elementary to doctorate, are included. Four variables describe different aspects of job attachment. First, if the MLB works in the Federal District (FD). Second, whether career or non-career civil servants occupy the commissioned position. Moreover, job attachment is also analyzed by hierarchical levels and advisory or executive functions. Chart 1 sets out details of the hierarchical 
levels of these posts as well as the most common functions associated to them.

Chart 1. Hierarchic levels and functions of DAS posts in the Federal Government

\begin{tabular}{ccc} 
Hierarchical & Executive & Functions \\
& Minister's Chief of Staff & Advisory \\
\hline Head of Department & Minister's Special Advisor \\
DAS 5 & Legal Advisor & \\
& Internal Control Secretary & \\
DAS 4 & General Coordinator & Advisor \\
DAS 3 & Coordinator & Technical Advisor \\
DAS 2 & Head of Division & Assistant \\
DAS 1 & Head of a Section & Technical Assistant
\end{tabular}

Source: Brazil (2015).

The professional background is calculated by two continuous variables: years of work and years as a team manager in the federal government.

Regarding performance dimension, as discussed previously, the capacity to influence decision making processes is highlighted as a core feature of the MLB literature. Scholars agree that the combination of technical and specialized insertion and management skills, position in the organizational structure, level of conflict with the professionals that are responsible for daily operations and sensitivity to understand the strategic context of the organization are determinant for the mid-level bureaucrats' influential performance (Currie and Procter, 2005; Kuratko et al., 2005; Kelly and Gennard, 2007). So, to capture this characteristic the survey answer for the following question was employed: "my ideas were considered in the process of decision making at the institution that I work". The frequency scale (" 1 " to " 5 " and " 99 " referring to the "not 
applicable") was recategorized as "99 = not applicable", " $1=$ Never, " 2 = Rarely" and " 3 = Sometimes" for the new category" little/no frequency"; " $4=$ Often" and " $5=$ Always" have been added in "high frequency" category.

Relationship is also an essential attribute to understand MLB's performance from the relations established with superiors, subordinates or other players involved in policymaking. Normally, to become effective, they connect the formulation process to the execution, or even make the translation among political and technical elements involved in public policies (Keiser, 2010; Johansson, 2012; Lotta, Pires and Oliveira, 2015). To cover this variable, a composite indicator was formulated, the Index of MLB Relationships (IBR), detailed in the paper's appendix 1. IRB is grounded on the following question: thinking about the work routine of your current position (consider the last year), indicate how often you interact (negotiate, send and receive orders, resolve, request information, etc.) with others.

Finally, the mid-level bureaucrats' performances have been analyzed by the diversity of their activities, including not only interpersonal contact and dialogue, but also related to other general categories, such as informational and decisional ones (Mintzberg, 1973; Chareanpunsirikul and Wood, 2002; Vie, 2010). To depict this characteristic, another composite indicator was formulated, Index of MLB Activities (IBA), also detailed in the paper's appendix 1. IRA is based on the following question: "thinking about your work routine in this current position (consider the last 12 months), indicate how often you perform the following activities".

In short, the variables used in the analysis were:

- IBR index (between 0 and 1);

- IBA index (between 0 and 1);

- DAS level (1 to 5);

- Advisor (yes or no);

- Career (non-career civil servant or career civil servant);

- Work in Federal District (yes or no);

- Years of working in the federal government (years);

- Years of management in the federal government (years); 
- Influence (yes or no);

- Age (years);

- Education (Elementary School, High School/Technical Education, Bachelor, Specialization, Master and Doctorate).

Then, a cluster analysis was employed in order to identify similar groups and to propose the MLB's typology. Therefore, the complete-linkage clustering (farthest neighbor) was employed, which aims at grouping together successive sets of variables or individuals until the distance between them starts to decrease (Johnson and Wichern, 2007). This method ensures that all observations in a cluster are within a maximum distance, and tends to produce clusters with similar diameters. In a previous step, Gower's coefficients were calculated (Gower, 1971) to establish the dissimilarity matrix (appendix 2). Note that this coefficient was used to jointly analyze qualitative and quantitative variables. As a result, the cophenetic correlation coefficient was 0.61 , which measures the degree of fit between the original similarity matrix and the simplified matrix provided by the clustering method, thus, five groups can be identified, as described below.

\section{Results}

Table 1 presents the relative frequency of each variable within their respective groups or types of mid-level bureaucrats. The percentage refers to the ratio between the number of MLBs having certain characteristic (for example, occupying a DAS 1) and the total MLBs in the group.

Table 1. Groups and General Descriptions

\begin{tabular}{|c|c|c|c|c|c|c|}
\hline & Group 1 & Group 2 & Group 3 & Group 4 & Group 5 & General \\
\hline \multicolumn{7}{|l|}{ DAS } \\
\hline 1 & 180 (10.2\%) & $\begin{array}{c}250 \\
(21.84 \%)\end{array}$ & $\begin{array}{c}333 \\
(36.12 \%)\end{array}$ & $\begin{array}{c}161 \\
(36.35 \%)\end{array}$ & 1004 (35.82\%) & $1928(27.24 \%)$ \\
\hline 2 & 301 (17.06\%) & $\begin{array}{c}204 \\
(17.82 \%)\end{array}$ & $189(20.5 \%)$ & $\begin{array}{c}126 \\
(28.45 \%)\end{array}$ & 860 (30.69\%) & $1680(23.74 \%)$ \\
\hline
\end{tabular}




\begin{tabular}{|c|c|c|c|c|c|c|}
\hline 3 & $416(23.57 \%)$ & $\begin{array}{c}250 \\
(21.84 \%)\end{array}$ & $\begin{array}{c}192 \\
(20.83 \%)\end{array}$ & 95 (21.45\%) & $590(21.05 \%)$ & $1543(21.8 \%)$ \\
\hline 4 & $577(32.7 \%)$ & $\begin{array}{c}353 \\
(30.83 \%)\end{array}$ & $\begin{array}{c}146 \\
(15.84 \%)\end{array}$ & 47 (10.61\%) & $292(10.42 \%)$ & $1415(20 \%)$ \\
\hline 5 & $291(16.49 \%)$ & $88(7.69 \%)$ & 62 (6.73\%) & $14(3.17 \%)$ & $57(2.04 \%)$ & $512(7.24 \%)$ \\
\hline \multicolumn{7}{|l|}{ Advisor? } \\
\hline No & $1273(72.13 \%)$ & $\begin{array}{c}456 \\
(39.83 \%)\end{array}$ & $\begin{array}{c}797 \\
(86.45 \%)\end{array}$ & $0(0 \%)$ & $2803(100 \%)$ & 5329 (75.29\%) \\
\hline Yes & 492 (27.88\%) & $\begin{array}{c}689 \\
(60.18 \%)\end{array}$ & $\begin{array}{c}125 \\
(13.56 \%)\end{array}$ & $443(100 \%)$ & $0(0 \%)$ & 1749 (24.72\%) \\
\hline \multicolumn{7}{|l|}{ Career } \\
\hline Non-career civil servant & $509(28.84 \%)$ & $0(0 \%)$ & $\begin{array}{c}123 \\
(13.35 \%)\end{array}$ & $443(100 \%)$ & $635(22.66 \%)$ & $1710(24.16 \%)$ \\
\hline Career civil servants & $1256(71.17 \%)$ & $1145(100 \%)$ & $\begin{array}{c}799 \\
(86.66 \%)\end{array}$ & $0(0 \%)$ & $2168(77.35 \%)$ & 5368 (75.85\%) \\
\hline \multicolumn{7}{|l|}{$\begin{array}{r}\text { Work in the Federal } \\
\text { District? }\end{array}$} \\
\hline No & $0(0 \%)$ & $166(14.5 \%)$ & $922(100 \%)$ & 95 (21.45\%) & $1463(52.2 \%)$ & 2646 (37.39\%) \\
\hline Yes & 1765 (100\%) & $\begin{array}{c}979 \\
(85.51 \%)\end{array}$ & $0(0 \%)$ & $\begin{array}{c}348 \\
(78.56 \%)\end{array}$ & $1340(47.81 \%)$ & 4432 (62.62\%) \\
\hline
\end{tabular}

Influential

\begin{tabular}{ccccccc} 
No & $0(0 \%)$ & $1145(100 \%)$ & $0(0 \%)$ & 413 & $2803(100 \%)$ & $4361(61.62 \%)$ \\
Yes & $1765(100 \%)$ & $0(0 \%)$ & $922(100 \%)$ & $30(6.78 \%)$ & $0(0 \%)$ & $2717(38.39 \%)$ \\
\hline
\end{tabular}

Education Level

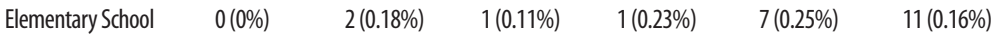

$\begin{array}{llllll}\text { High School/Technical } & 56(3.18 \%) & 54(4.72 \%) & 30(3.26 \%) & 61(13.77 \%) & 216(7.71 \%)\end{array} \quad 417(5.9 \%)$ Education

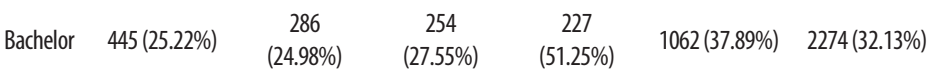

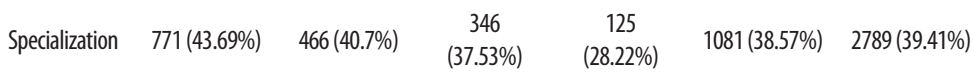

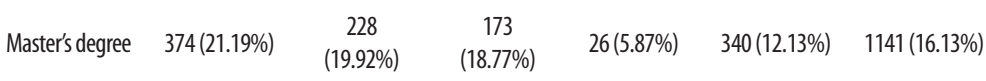

\begin{tabular}{rcccccc} 
Doctorate degree & $119(6.75 \%)$ & $109(9.52 \%)$ & $118(12.8 \%)$ & $3(0.68 \%)$ & $97(3.47 \%)$ & $446(6.31 \%)$ \\
\hline IRB Average & 0.61 & 0.54 & 0.59 & 0.52 & 0.52 & 0.55 \\
\hline IBA Average & 0.76 & 0.68 & 0.75 & 0.61 & 0.65 & 0.69 \\
\hline Age Average & 42.99 & 44.96 & 48.06 & 40.12 & 44.88 & 44.53 \\
\hline
\end{tabular}




\begin{tabular}{rcccccc}
\hline $\begin{array}{c}\text { Years of working in } \\
\text { the federal gover- } \\
\text { nment (average) }\end{array}$ & 13.64 & 16.13 & 17.41 & 8.55 & 14.20 & 14.43 \\
\hline $\begin{array}{r}\text { Years as manager in } \\
\text { the federal gover- } \\
\text { nment (average) }\end{array}$ & 7.19 & 7.14 & 8.57 & 2.73 & 6.08 & 6.64 \\
\hline MLBs & 1765 & 1145 & 922 & 443 & 2803 & 7078 \\
\hline
\end{tabular}

Source: Author, based on Mid-level Bureaucrats Surveys.

Before discussing the MLB's tentative typology, let's first describe the main features of each group.

\section{Group 1}

Group 1 has the second largest number of the MLBs sample, the highest IBR (0.61) and IBA (0.76) indexes average. They are all influential bureaucrats in the decision-making process. Almost half of them occupy DAS $4(32 \%)$ or 5 (16\%). The majority work with executive functions, $72 \%$, while $28 \%$ work as advisors. Virtually, the same proportions apply to career (71\%) and non-career civil servants (29\%). These two variables distributions converge with the same pattern of the DAS population (Brazil, 2015). All MLBs in the group 1 works in the Federal District and over $70 \%$ hold a postgraduate degree (specialization, master or doctorate). Surprisingly, the average working years in the federal public administration is the second smallest and so is their age average.

\section{Group 2}

This group typically is composed by advisors (60\%) with DAS 3 to 5 . In the same proportion, they all belong to a permanent career in the civil service. Most of them work in the FD (85\%), are well educated (70\% postgraduate) and have the third highest IRB and IBA averages. Lastly, the group has the second highest average age and years of working; however, its influential capacity in the decision-making is low or absent. 


\section{Group 3}

The bulk of bureaucrats in group 3 has executive functions and comes from permanent careers in the federal government, both variables sit around $86 \%$. They mostly hold lower commissioned positions, $78 \%$ with DAS 1 to 3, don't work in the Capital and have also a distinguished educational level (69\% postgraduate). Regarding performance, group 3 has the second highest average in the IRB (0.59) and IBA (0.75) indexes and is influential in decision-making. These mid-level bureaucrats, on average, are the oldest and the most experienced in government and also as team managers.

\section{Group 4}

Advisors and non-career civil servants exclusively compose group 4. The majority works in the Federal District (78\%), occupies lower DAS ( 1 to 3 ), about $87 \%$, and has, on average, the worst educational background. Their indexes of relationships and activities are also the lowest and just few of them are influential (7\%). The MLBs from this group are the youngest ones and the least experienced both in working and managing in the federal government.

\section{Group 5}

The largest group of mid-level bureaucrats, representing $40 \%$ of the sample. They all work with executive functions and, on average, are concentrated in the lowest commissioned positions, $88 \%$ from DAS 1 to 3. The majority of them takes part of a permanent career, nevertheless, almost half works outside the Capital. They have no influence on decision-making, displays low IRB and IBA indexes and almost 55\% have postgraduate degree. Their average of experience in the federal administration is around 14 years and their age about 45 years old.

\section{Analysis}

The cluster analysis results demonstrated that even in this specific segment of the civil service, a heterogeneity pattern prevail. So, this assumption is confirmed and one can move forward to discuss how 
these dimensions' diversity can be used to set up a mid-level bureaucrats' typology. The two charts below (Figure 1) correlate the most important variables employed to explore the MLB heterogeneity.

Figure 1. Performance Dimensions and Hierarchical/Educational Levels

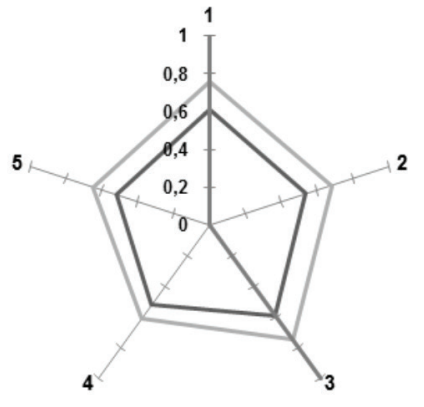

-IRB Mean

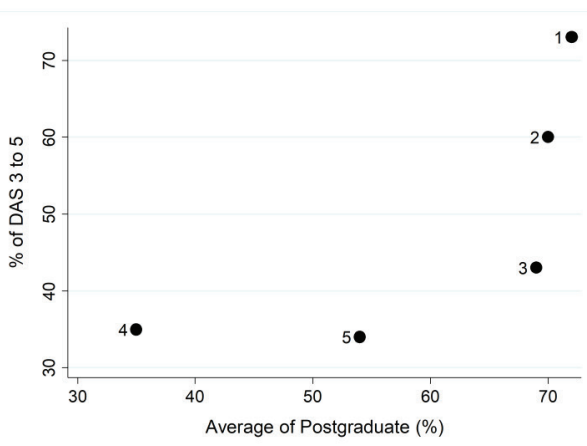

Source: Authors, based on Mid-level Bureaucrats Surveys.

The radar chart displays three performance variables - influence,relationship and activities indexes that express, under different approaches, aspects of the professional's skills and prominence in government. First, the chart reinforces that only two groups of MLBs (1 and 3) are actually capable of influencing the decision making process. The same groups also have the highest averages of IRB and IBA indexes, i.e., they are the most connected and perform a more complex list of duties. Despite the fact that group 2 is not influential, they have the third best indexes of relationship and activities, while group 4 and 5 are quite similar in these matters.

Previous research has shown that the degree of MLBs relationship and their activities' level of complexity tend to increase accordingly to their influential capacity and the position they occupy (Cavalcante, Lotta and Kasai, 2016). In this sense, one can similarly suppose that the highest the DAS, more powerful the bureaucrat tends to be. The scatter plot above demonstrates the simple correlation between the highest positions (DAS 3 to 5) and 
the educational level - average of postgraduate in the group. Once again the first three groups are better educated than groups 4 and 5 .

On the other hand, the differences among them, regarding the posts, are very significant. Group 1, followed by group 2, clearly concentrates higher percentage of top DAS, whereas the rest of them is situated below or close to $40 \%$ of the DAS 3 to 5 . It is reasonable to understand groups 4 and 5 in that situation, however, the third group, as mentioned before, is more powerful even compared to group 2. A possible explanation lies on the fact that MLBs from group 3 all work out of the Federal District and most of the decentralized federal units, including agencies, museums, hospitals and so on, are, generally, managed by lower DAS. In these cases, despite the position level, these bureaucrats are, on average, well qualified and experienced, with a broad network and, consequently, are influential and busy.

Hence, to describe each MLB's types, one has to start referring to an analogy of the well-known European social structure in the Middle Ages (Burns, 1979). Based on the feudalism social hierarchy, the empirical results are translated into types incorporated in the mid-level bureaucrats. It is worth mentioning that this is just an illustrative exercise to help reinforcing the heterogeneity among the MLBs. The purpose is not to systematically compare these different objects, but only to show how the analyzed dimensions of the mid-level bureaucrats can also highlight to some extent a degree of stratification.

Beyond this segment, in the federal government hierarchy, depicted in figure 2, the elected officials are at the top. Back in the middle ages, the 'Church' has occupied this place, grounded in the religion legitimacy. Nowadays, democracy provides the legitimacy basis for the elected officials to rule and decide in policymaking. In the second level, also not subject of this inquiry, the top officials may be considered the most important stakeholders in the bureaucratic pyramid, being illustratively compared to the 'King' during the feudal society. As the elected officials, high-level bureaucrats' appointment, behavior and performance follow a different pattern 
from the rest of the bureaucrats. Jumping to the triangle base, right below the MLBs types, there are the 'Peasants' representing the low-level and street level bureaucracies. In the Brazilian case, usually, the former works with the MLB but without DAS position, while the latter is the one that interacts directly with citizens in processes of policy execution (Lipsky, 1980).

In the intermediate segment of the civil service, the groups generated by the cluster analysis were fitted into the pyramid. In these particular layers for the mid-level bureaucrats, five groups were organized in three levels, regarding the dimensions and variables employed during the statistical analysis and, especially, the results discussed above.

Figure 2. MLB's Typology and its Middle Ages Analogy

Church

(Elected Officials)

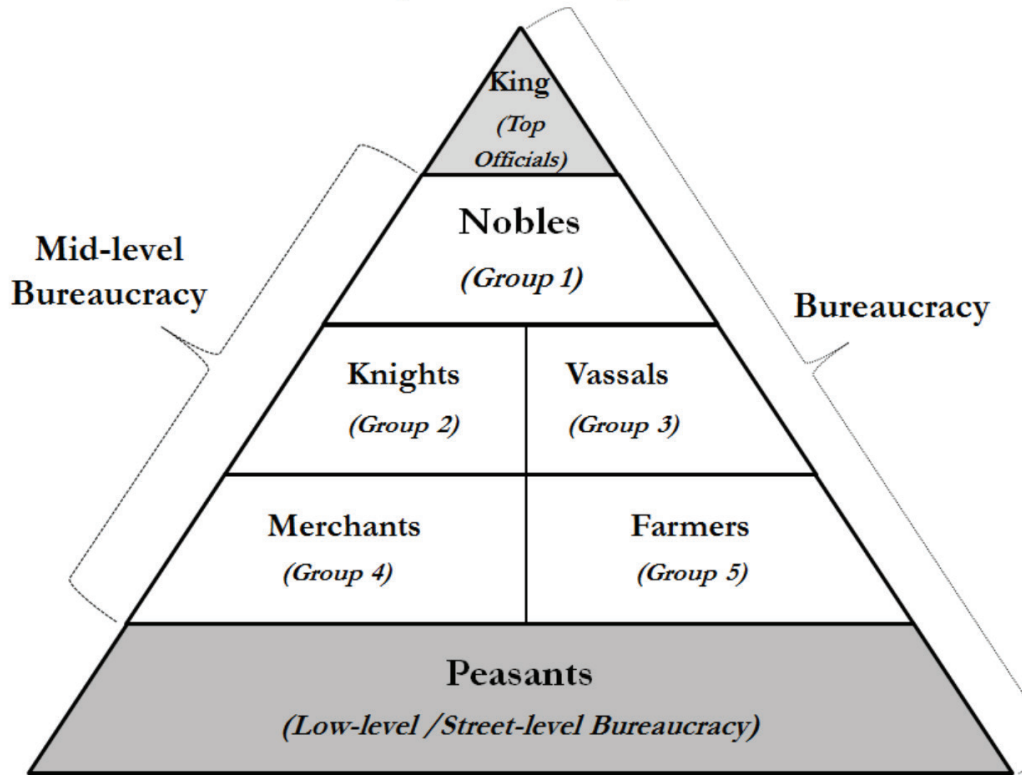

Source: Authors, based on Mid-level Bureaucrats Surveys. 
The typology can be summarized as follows:

- Nobles (group 1): The most powerful ones, as in the Middle Ages, they are responsible for the daily essential management tasks, in this case, the policy implementation process. They hold the highest DAS in the intermediate positions, usually perform a variety of work activities, have considerable management background, and are well educated, influential and very connected.

- Knighs (group 2): This type of mid-level bureaucrats, as the Knights in the feudal system, is composed by the civil service's elite - part of permanent career in the top posts and well educated. Nevertheless, without the Nobles's power and influence. They are mostly advisors and averagely connected and busy with the public sector's activities.

- Vassals (group 3): Although these MLBs are seldom a representative of the elite, different from the Nobels and Knights, which can be perceived by their lower commissioned positions and because they do not work in the Federal District, the Vassals type overcome it with high education level and experience in government and team management. As well as in the Middle Ages, Vassals perform, usually, relevant management responsibilities in decentralized units (military support and mutual protection back then). Therefore, they are influential in the policy decision process and very connected and multitasking.

- Merchants (group 4): this mid-level bureaucrats differ completely from the other types because they are all advisors and without a permanent link with the civil service, exactly like the Merchants during the feudalism period, since this class was typically nomadic people established in a particular setting. The MLBs Merchants are young with low experience and educational level, subsequently, not influential and less connected and busy.

- Farmers (group 5): the largest type of mid-level bureaucrats, as the small rural owners in the intermediate layer of Middle 
Ages social structure, is not influential, less educated and connected. The totality of them works in executive activities and is very concentrated in the lowest commissioned positions, however, spread all over the Brazilian states.

\section{Final Remarks}

This paper is a fruitful analysis, and further investigation of a comprehensive research started in 2014 andintended to deepen the understanding of mid-level bureaucrats of the Brazilian federal government (Enap, 2014; Cavalcante and Lotta, 2015). Exactly to address one of the issues raised by this research agenda, the MLBs heterogeneity, this inquiry's goals are not only to prove how diverse the mid-level bureaucrats are, but mainly to make progress at exploring in which extent they differ.

As shown in the theoretical section, typologies are not a trivial exercise in this field of study. The literature, however, covers a substantial number of researches focused on explaining how bureaucrats are a complex and unlike subject. Besides, they also focus on how advancing the comprehensive knowledge of them can help to investigate their impacts on policymaking and on social and economic development.

Furthermore, there is a gap in the literature that does not cover the mid-level bureaucrats approach, which was showed in the present paper. MLBs are recognized as actors who play specific and important roles in policymaking as they connect different levels of bureaucrats and translate the formulation to implementation and vice versa. Then, this paper proposes an original typology of bureaucrats situated in intermediate layer of the civil service structure, consists in a deliberated effort to fill this gap. To do so, relying on a resourceful database highly representative of the Brazilian MLB, a sophisticated analytical strategies was employed, primarily, complete-linkage clustering to analyze simple and composite indicators regarding important bureaucracy's dimensions, such as profile, job attachment, professional background and performance. 
The empirical results were quite interesting. The cluster analysis provided five distinguished groups or types that were used to sort in a bureaucrat hierarchical structure. In order to facilitate these types' description, they were compared to well-known social classes of the Middle Ages. This analogy served merely as an illustrative exercise that helped to highlight the main characteristics of MLB's typology.

First, despite the heterogeneity, in general, this specific segment of the civil service is well educated with years of public sector and management's experience, which conflicts with the common sense. Besides, the empirical evidence also confirms the presence of meritocratic mechanisms in the Brazilian federal government, already highlighted in the literature (IADB, 2006; Evans and Rauch, 2014; Cavalcante and Lotta, 2015; Lopez, 2015), since professional background and formal education have positive relation with commissioned position appointments.

Additionally, the typology demonstrated the existence of an elite of MLBs - nobles, vassals and knights; however, even inside this prominent segment there is stratification. Considering the performance dimensions (influence, relationship and activities), nobles are at the top, followed by vassals and knights, in this particular order. In the pyramid basis, the clusters analysis showed two types - merchants and farmers - that are very far from the elite, mostly because they have, overall, less qualification and resources.

The evidences are, in fact, interesting and unique, but why is this typology important? The assumption that bureaucracy is a relevant player in the policymaking process is already a consensus; notwithstanding, we strongly believe that it is not enough both for theoretical and practical purposes. In proving and describing that bureaucracy, especially the mid-level, must not be seem as a simple analytical construction, the MLB's typology contributes to accurate the understanding of their behaviour and performance inside the public sector. In this sense, the research's results help scholars and, above all, the government to formulate different policies to select, train and foster better performance accordingly to each type of 
bureaucrat and based on precise knowledge of their characteristics and skills.

\section{References}

ABERS, Rebecca; KECK, Margaret (2013). Practical Authority: Agency and Institutional Change in Brazilian Water Politics. Nova Iorque: Oxford University Press.

ABERS, Rebecca (2015). "Ativismo na burocracia? O médio escalão do Programa Bolsa Verde". Burocracia de médio escalão: perfil, trajetória e atuação. pp. 43-175.

ALEXANDER, Damon; LEWIS, Jenny M.; CONSIDINE, Mark (2011). "How Politicians and Bureaucrats Network: a comparison across governments”. Public Administration, 89: 1274-1292.

BENZÉCRI, J-P (1992). Correspondence analysis handbook. Marcel Dekker.

BEVIR, Mark; RHODES, Rod A.W. (2010). The State as Cultural Practice. Oxford: Oxford University Press.

BERSCH, Katherine; TAYLOR, Matthew M. (2013). "State Capacity, Bureaucratic Politicization, and Governance Outcomes". In: American Political Science Associaton Meeting, Chicago. Annals of the American Political Science Associaton Meeting.

BRAZIL (2015). Boletim Estatístico Pessoal e Informações

Organizacionais. v. 18. n. 212, Brasília: janeiro.

BREHM, John; GATES, Scott (1997). Working, Shirking, and Sabotage: Bureaucratic Response to a Democratic Public. Ann Arbor: University of Michigan Press.

CAVALCANTE, Pedro; LOTTA, Gabriela (2015). Burocracia de Médio Escalão: perfil, trajetória e atuação. ENAP, Brasília.

CAVALCANTE, Pedro; CAMOES, Marizaura R.S.; KNOPP, Márcia (2015). Burocracia de médio escalão nos setores governamentais: semelhanças e diferenças. In: Pedro Cavalcante; Gabriela Lotta. (Org.). Burocracia de Médio Escalão: perfil, trajetória e atuação. 1ed. Brasília: Escola Nacional de Administração Pública - Enap, v. 1, p. $57-90$. 
CHAREANPUNSIRIKUL, Suchada; WOOD, Roy C. (2002). "Mintzberg, managers and methodology: some observations from a study of hotel general managers" Tourism Management, No.23, pp.551-556.

CURRIE, Graeme; PROCTER, Stephen (2005). “The Antecedents of Middle Managers' Strategic Contribution: The Case of a Professional", Journal of Management Studies, Vol.42, No.7, November, pp.99-117.

DALTON, Melville (1959). Men who manage. New York: John Wiley \& Sons.

DE BONIS, Daniel (2008). O dirigente público como categoria analítica: um exercício de definição. Dissertação de mestrado apresentada à EAESP-FGV.

DEMIR, Tansu; REDDICK, Christopher G. (2012). “Understanding Shared Roles in Policy and Administration: An Empirical Study of Council-Manager Relations". Public Administration Review Volume 72, Issue 4, pages 526-535, July/August.

DOWNS, Anthony (1967). Inside bureaucracy. Boston: Little, Brown and Company.

DROR, Yehezkel (1979). "O Administrador Público tipo delta para o Século XXI”. Revista do Serviço Público, ano 48, no. 2, mai-ago, 1997.

DUBOIS, V. La Vie au Guichet: Relation Administrativeet Traitement de la Misère, Etudes politiques. Paris: Economica, 1999.

BURNS, E. História da Civilização Ocidental. Vol. 1. Editora Globo.

EVANS, Peter; RAUCH, James (2014). Burocracia e crescimento: uma análise internacional dos efeitos das estruturas do Estado "weberiano" sobre o crescimento econômico. Revista do Serviço Público - RSP, v. 65, n. 4, p. 407-437.

GOWER, John C. (1971). "A general coefficient of similarity and some of its properties." Biometrics 857-871.

HAIR, Joseph F. et al. (2005). Análise Multivariada de Dados. $5^{\mathrm{a}}$ edição. Porto Alegre: Bookman. 
HOWLETT, Michael (2011). "Public Managers as the Missing Variable in Policy Studies: An Empirical Investigation Using Canadian Data". Review of Policy Research, Volume 28, Issue 3, pages 247-263, May.

HOYLER, T and CAMPOS, P.(2016). Backstage bureaucrat's dilemmas and the informality within the State. Working paper prepared to be presented at the RC21 International Conference on "The transgressive city: Comparative perspectives on governance and the possibilities of everyday life in the emerging global city" Mexico City, 2123 July.

HUPE, Peter; HILL, Michael; BUFFAT, Aurélien (2015). Understanding Street-Level Bureaucracy. Policy Press, University of Bristol.

HUPE, Peter (2007). Street-Level Bureaucracy and Public Accountability. Public Administration, vol. 05.

HUISING, Ruthanne; SILBEY, Susan S. (2011). Governing the gap: Forging safe science through relational regulation. Regulation \& Governance, 5: 14-42.

IADB. Banco Interamericano de Desarrollo (BID) (2006). The Politics of Policies: Economic and Social Progress in Latin America, 2006 Report. Harvard University David Rockefeller Center for Latin American Studies Washington, D.C.

JOHANSSON, Vicki (2012). "Negotiating Bureaucrats". Public Administration, Volume 90, Issue 4, pages 1032-1046, December. JOHNSON, Richard A.; WICHERN, Dean W. (2007). Applied multivariate statistical analysis. Vol. 6. Upper Saddle River, NJ: Prentice hall.

KAUFMAN, Herbert (1960). The forest ranger: a study in administrative behavior. Baltimore: Johns Hopkins Press.

KEISER, Lael (2010). 'Understanding Street-Level Bureaucrats' Decision Making: Determining Eligibility in the Social Security Disability Program". Public Administration Review, Volume 70, Issue 2, pages 247-257, March/April. 
KELLY, James; GENNARD, John (2007). "Business strategic decision making: the role and influence of directors", Human Resource Management Journal, Vol 17, No, 2, pp.99-117.

KURATKO, Donald F. et al. (2005). "A model of middle-level managers' entrepreneurial behavior". Enterpreneurship Theory \& Practice, November, pp.699-716.

LIPSKY, Michael (1980). Street-Level Bureaucracy. New York: Russell Sage Foundation.

LONGO, Francisco (2003). A consolidação institucional do cargo de dirigente público. Revista do Serviço Público 54(2):7-33, abr-jun.

LONGO, Francisco (2007). Mérito e Flexibilidade. A Gestão das Pessoas no Setor Público. São Paulo: FUNDAP (1 $1^{\text {a }}$ edição em espanhol, 2004).

LOPEZ, Felix; BUGARIN, Maurício; BUGARIN, Karina (2014). Turnover of political appointments in Brazil: key indicators 1999-2012. International Journal of Cooperation Studies, v. 22, p. 109-120.

LOPEZ, Felix Garcia. (Org.) (2015). Cargos de confiança no presidencialismo de coalizão brasileiro. 1ed. Brasília: Editora IPEA, p. 165-208.

LOTTA, Gabriela (2015). Burocracia e Implementação de Políticas de Saúde. Ed. Fiocruz, Rio de Janeiro.

LOTTA, Gabriela, Pires, Roberto Rocha C., Oliveira, Vanessa (2014). "Burocratas de Médio Escalão: Novos Olhares Sobre Velhos Atores da Produção de Políticas Públicas". Revista do Serviço Público.

LOUREIRO, Maria Rita; ABRUCIO, Fernando; PACHECO, Regina (orgs) (2010). Burocracia e Política no Brasil Contemporâneo, Rio de Janeiro: Ed. FGV.

MARDIA, K.V.; KENT, J.T.; BIBBY, J.M. (1979). Multivariate analysis. London: Academic Press.

MAYNARD-MOODY, Steven; MUSHENO, Michael (2003). Cops, Teachers, Counselors: Stories from the Front Lines of Public Service. Ann Arbor: University of Michigan Press. 
MEYER, Renate E. et al. (2013). "Of bureaucrats and passionate public managers: Institutional logics, executive identities, and public service motivation". Public Administration.

MINTZBERG, Henry (1973). The nature of managerial work. New York: Harper \& Row.

NENADIC, O., Greenacre, M. (2007) Correspondence Analysis in $\mathrm{R}$, with two- and three-dimensional graphics: The ca package. Journal of Statistical Software 20(3):1-13.

OLIVEIRA, Clarisse (2007). O servidor público brasileiro: uma tipologia da burocracia. Revista do Serviço Público Brasília 58 (3): 269-302 Jul/Set.

OLIVEIRA, Vanessa E (2009). "Instituições, burocracia e produção de políticas públicas: o caso da política estadual de saúde”. Artigo apresentado no $33^{\circ}$ Encontro Anual da ANPOCS, Caxambu, MG.

OLIVEIRA, Vanessa E.; ABRUCIO, Fernando L. (2011). "Entre a política e a burocracia: a importância dos burocratas de nível médio para a produção de políticas públicas em saúde e educação". Artigo apresentado no $35^{\circ}$. Encontro Anual da ANPOCS, Caxambu, MG.

Organization for Economic Co-operation and Development (OECD) (2008). Handbook on Constructing Composite Indicators: methodology and userguide.

PIRES, Roberto (2012). "Burocracias, gerentes e suas "histórias de implementação": narrativas do sucesso e fracasso de programas federais" in: FARIA, C. A. P. (Org.) Implementação de Políticas Públicas: teoria e prática. Belo Horizonte: Editora PUC Minas, pp.182-220.

PIRES, Roberto (2015). Por Dentro do PAC: arranjos, dinâmicas e instrumentos na perspectiva dos seus operadores. In: Cavalcante, P. e Lotta, G. Burocracia de Médio Escalão. ENAP.

PIRES, Roberto (2009). Estilos de implementação e resultados de políticas públicas: fiscais do trabalho e o cumprimento da lei trabalhista no Brasil. Dados, v. 52, n. 3, p. 735-769. 
SCHNEIDER, Ben Ross (1994). Burocracia pública e política industrial no Brasil. Tradutor: Pedro Maia Soares. São Paulo: Sumaré.

SPINELLI, Mário V. (2016). Street-level corruption: fatores institucionais e políticos da corrupção burocrática. Tese de doutorado em Administração Pública e Governo, FGV.

VAKKURI, Jarmo (2010). Struggling with ambiguity: Public Managers as User of NPM-Oriented Management Instruments. Public Administration, Volume 88, Issue 4, pages 999-1024, December.

VIE, Ola E. (2010). Have post-bureaucratic changes occurred in managerial work?, European Management Journal, N.28, pp.182- 194.

WATERMAN, Richard W.; WOOD, B. Dan (1993). "Policy Monitoring and Policy Analysis." Journal of Policy Analysis and Management 12: 685-99.

WILSON, James Q. (1968). Varieties of police behavior: the management of law and order in eight communities. Cambridge: Harvard University Press.

\section{APPENDIX 1 - Mid-level Bureaucrat's relationship and activities indexes}

In this section the methodology for the preparation of the synthetic Index of MLB Relationships (IBR) and Activities (IBA) are presented. Initially, an original frame was chosen, the factors that best represent the analyzed phenomenon. In this case, the frequency of bureaucrat's interaction with governmental and non-governmental players and the frequency of activities' performed in a yearlong. The second step involves the selection of the primary data that had been transformed to allow comparisons (OCDE, 2008). The frequencies of responses were converted into numbers from two survey questions - Always (5); Often (4); Sometimes (3); Rarely (2) and Never (1).

The relationship question is: thinking about the work routine of your current position (consider the last year), indicate how often you 
interact (negotiate, send and receive orders, resolve, request information, etc.) with others. Table 2 shows the set of players/institutions (IRB primary indicators).

The activity question is: thinking about your work routine in this current position (consider the last 12 months), indicate how often you perform the following activities, listed in the table 3.

In the next step, the Principal Component Analysis method (PCA) was employed, a type of factor analysis, which, in short, applies to the identification of factors that objectively point to the aggregation and reduction of a number of measures. The method provides reduced loss of explanatory power of the original data and a lesser degree of subjectivity of the researcher (Hair et al., 2005). The main purpose is to create new variables that are linear combinations of the primary variables. Thus, unlike the arbitrary definition of weights, the methodology takes advantage of the correlation between indicators and creates an index corresponding to a weighted average of these variables.

Once built, the indexes were transformed, aiming at normalization of its values within the 0 - 100 range. Thus, the following formula was used:

$$
\mathrm{IS}_{\mathrm{i}}^{\mathrm{X}}=\left[\frac{\mathrm{Xi}-\mathrm{X} \min }{\mathrm{X} \max -\mathrm{X} \min }\right] * 100=0 \ldots 100
$$

Where,

IS = Synthetic Index

$\mathrm{X}_{\mathrm{i}}=$ Observed Index

$\mathrm{X}_{\min }=$ Minimum value

$\mathrm{X}_{\max }=$ Maximum value

Finally, Table 2 and 3 also include the percentage variation of the first component and the respective factor loadings used for the calculation of indexes, separated by the dimension indicators: 


\section{Table 2. List of variables and loadings of the first component}

\begin{tabular}{|c|c|c|c|}
\hline & Dimension & Primary Indicator & Eigenvalue \\
\hline & & Superiors & \\
\hline & Intra-organizational & Subordinates & 1.4 \\
\hline & & $\begin{array}{l}\text { Colleagues of the same } \\
\text { hierarchical level }\end{array}$ & \\
\hline & & 0ther bodies (except Civil Office) & \\
\hline & & Civil Office & \\
\hline & & Politicians & \\
\hline \multirow[t]{6}{*}{ Index of MLB Relationships (IBR) } & Inter-government & $\begin{array}{l}\text { Control bodies (General } \\
\text { Comptroller of the Union, } \\
\text { Federal Court of Accounts) }\end{array}$ & 2.74 \\
\hline & & Judiciary bodies & \\
\hline & & States and municipalities & \\
\hline & & International organizations & \\
\hline & Non-governmental & Media & 2.45 \\
\hline & & Civil society & \\
\hline
\end{tabular}

Source: Authors, based on Mid-level Bureaucrats Surveys.

\section{Table 3. List of variables and loading of the first component}

\begin{tabular}{cc}
\hline \multicolumn{1}{c}{ Primary Indicator } & Eigenvalue \\
\hline $\begin{array}{c}\text { Contacts and individual conversations (e.g. phone calls, clearances, etc.) } \\
\text { Participate in meetings with internal agency staff } \\
\text { Attend meetings with external parties } \\
\text { Provide or validate data for of systems information }\end{array}$ \\
$\begin{array}{c}\text { Index of MLB } \\
\text { Activities (IBA) }\end{array}$ \\
Produce and validate internal documents (e.g.technical opi- \\
nion, reports, plans, spreadsheets and presentations) \\
Produce and validate normative documents (e.g. drafts of de- \\
cree resolutions or ordinance or regulation) \\
Produce and validate external circulation of documents (e.g. re- \\
leases, flyers, brochures and manuals)
\end{tabular}

Source: Authors, based on Mid-level Bureaucrats Surveys. 


\section{APPENDIX 2 - Gower's coefficient}

Gower index is a similarity coefficient that simultaneously combines several types of variables (qualitative and quantitative). To build a dissimilarity matrix for the clustering method the similarity between objects of interest must be calculated. If the variable is qualitative, the similarity between variables is calculated by the arithmetic mean of the comparisons between variables, which can assume two values, zero (when there is disagreement between objects) and one (when there is agreement between the objects); if the variable is continuous, the similarity is given by the ratio between the deviation and the maximum deviation from other values of other variables. Thus, the coefficient is given as follows:

$$
\mathrm{Sij}=\frac{\sum_{\mathrm{k}=1}^{\mathrm{p}} \mathrm{w}_{\mathrm{k}} \mathrm{s}_{\mathrm{k}}}{\sum_{\mathrm{k}=1}^{\mathrm{p}} \mathrm{s}_{\mathrm{k}}}, \mathrm{S}_{\mathrm{if}} \in[0,1]
$$

Where,

$\mathrm{W}_{\mathrm{k}}$ : flexible element (Kronecker delta)

$\mathrm{S}_{\mathrm{k}}$ : similarity (qualitative or quantitative)

Sij: similarity between objects $i$ and $j$.

p: number of variables.

If the value is close to one, it means that the two objects do not differ in characteristics, while if the value is close to zero, then, the two objects are very different.

\section{Abstract}

The paper's main goal is to present an original typology of bureaucrats, situated in intermediate layer of the civil service structure. This specific set of players, the mid-level bureaucrat (MLB), is seen as a strategic group, primarily, because of its connection role and position between the top officials and the policy executors. Despite their relevance and well-known heterogeneity, few studies have explored this diversity and the effects in the policymaking. In order to fulfill this gap and deepen the understanding of the MLBs, this article proposes a typology that includes crucial dimensions, such as profile, background and performance, and, 
thus, empirically confirms the heterogeneity assumption in the Brazilian federal civil service.

Keywords: mid-level bureaucrat; typology; policymaking; Brazil.

\section{Resumo}

O principal objetivo deste artigo é apresentar uma tipologia original de burocratas situados no nível intermediário da estrutura do serviço público. Esse conjunto específico de atores, os burocratas de médio escalão (BME), é visto como um grupo estratégico em função do seu papel de ligação e posição entre o alto escalão e os executores das políticas. Apesar de sua relevância e da reconhecida heterogeneidade, poucos estudos têm essa diversidade e efeitos no policymaking. Para cobrir esta lacuna e aprofundar na compreensão dos BMEs, este artigo propõe uma tipologia que inclui importantes dimensões, como perfil, trajetórias e desempenho, e assim, confirma empiricamente o pressuposto da heterogeneidade no serviço público federal brasileiro.

Palavras-chave: burocrata de médio escalão; tipologia; formulação e implementação de políticas públicas; Brasil.

Recebido em 07 de julho de 2017

Aprovado em 01 de abril de 2018 